成人鼠径へルニアに対するメッシュプラグ法と比較した Kugel 法の優位性

あかね会土谷総合病院外科, 中国労災病院外科*, 国立病院機構東広島医療センター外科**

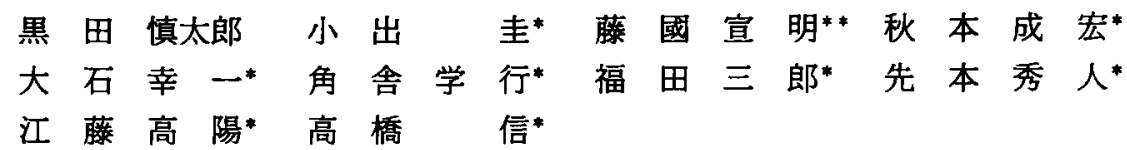

近年, 成人䖢径へルニアの手術のなかでも数多くの利点を持つ Kugel 法が広まりつつ ある. Kugel 法は他の tension free の方法と比較して, 手術操作も少なく単純な術式で あるが，パッチを留置する腹膜前腔は解剖学的に馿染みが薄いため, 習熟にある程度の 経験を要するのが難点と言われる. 今回われわれは, Kugel 法導入後16力月間に同一術 者が行った38例について手術時間の learning curve を算出し, 技術の習熟に要する症例 数を検討した. また, 主に Kugel 法導入前に行った37例のメッシュプラグ法と比較した. 平均手術時間は Kugel 法29.6分，メッシュプラグ法47.3分であった。一人の術者で Kugel 法の手技が安定するには15〜20例の経験を要すると思われた. Kugel 法はある程 度の経験を要するものの, 習熟すれば非常に短時間て確実に施行できる, 利点の多い方 法であると考えられた。

索引用語：臼径ヘルニア, Kugel 法

\section{緒 言}

近年では，成人鼠街ヘルニアの手術はメッシュを用 いた tension free の修復法が標準治療法である゙.中で も形状記境リングを持った棈円形のポリプロピレンメ ッシュ (Kugel ${ }^{\mathrm{TM}}$ hernia Patch ; 以下 Kugel パッチ)

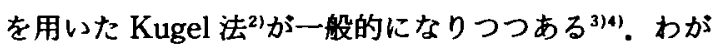
国では2000年より Kugel パッチの使用が開始され，林 メディコン社の調查（平成13年厚生労働省医科診療件 数調査結果をべースに推測）によると2004年には成人 鼠径ヘルニア手術全体の約 $5.7 \%$ を占めており，現在も 尚, 徐々に広まりつつあると推定される（図 1 ）。

Underlay patch repairである Kugel 法は物理的に は非常に強固な補強てある.また,他の tension free の 方法と比較して, 操作も少なく単純な術式であるか， パッチを留置する腹膜前禁は解剖学的に馿染みが薄い ため, その術式は初期にはなかなかわかりにくく, 習 熟するためにはある程度の経験を要するのが難点であ ると言われている5!. 今回われわれは, 同一術者が行っ

2006年 4 月 10 日受付 2006 年 7 月18日採用 〈所属施設住所〉

干730-8655 広島市中区中島町 3-30
た Kugel 法38例について, 同術者が行った37例のメッ シュプラグ法と比較し, 手術時間の learning curveを 算出し，より早く安定した手技を確立するための検討 をした。そして, 習得することのメリットや, Kugel 法 の優位性について若干の文献的考察を加えて報告す る.

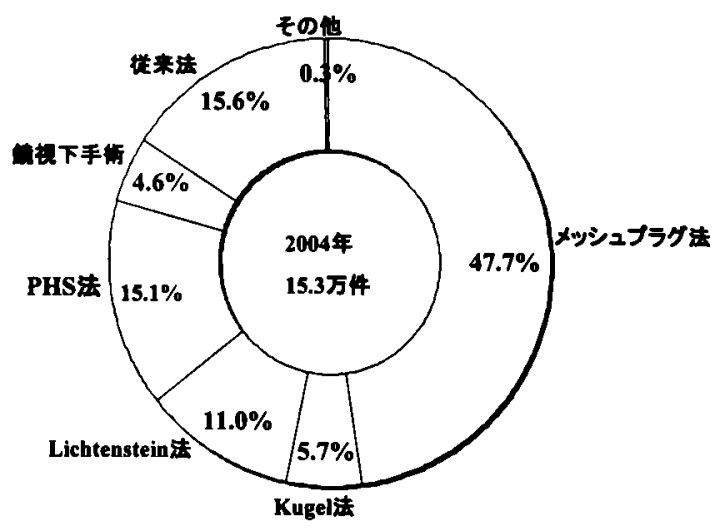

图 1 日本における成人鼠径ヘルニア手術の内わけ：平 成13年厚生労㖶省医科診療件数調查結果をべースに怢 メティコンが推測. 
表 1 Kugel 法とメッシュプラグ法の対象，成継

\begin{tabular}{|c|c|c|}
\hline & Kugel 法 & メッシュプラグ法 \\
\hline 症例数 & 38 & 37 \\
\hline 男:女 & $37: 1$ & $34: 3$ \\
\hline 年齢 (平均) & 18-84葴 (60.9歳) & $26-86$ 葴 (67.7歳) \\
\hline 右:左 & $17: 21$ & $25: 12$ \\
\hline 直接型：関節型：再発型 & $9: 27: 2$ & $12: 22: 4$ \\
\hline 平均手術時間 (分) & 29.6 & 47.3 \\
\hline 最近20症例平均手術時間(分) & 21.9 & 36.3 \\
\hline 再発症例(例) & 1 & 1 \\
\hline 合併症 & 泰液䏩 5 例, 皮下血腫 1 例 & なし \\
\hline 平均入院日数 (日) & 6.7 & 6.9 \\
\hline
\end{tabular}

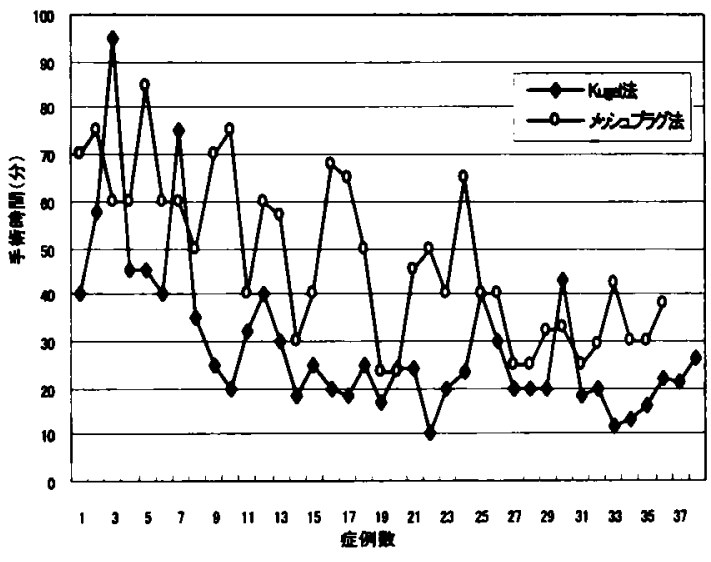

图 2 Kugel 法とメッシュブラグ法の手術時間の推移

\section{対象と方法}

\section{1) 対象}

当施設での Kugel 法过入時である平成16年 4 月よ り平成18年 3 月までに, 同一術者（外科レジデント） が Kugel 法で行った成人鼠径へルニア38例と，主に Kugel 法运入以前の平成15年 4 月より平成17年 7 月ま でに同術者がメッシュプラグ法で行った成人鼠径へル ニア37例を対象とした。平成16年 4 月より平成17年 7 月までの両術式が重複した時期の術式選択は無作為に 行われ, 平成17年 7 月以降は完全に Kugel 法に移行し た. Kugel 法は，男性37例，女性 1 例，年齢：18〜84 歳(平均：60.9葴), 部位は右：17例, 左：21例(両側： 4 例), 分類は直接型：9例, 間接型：27例, 再発型： 2 例であった。一方, メッシュプラグ法は, 男性34例, 女性 3 例, 年齢：26 86歳 (平均：67.7墄), 部位は右：
25例, 左：12例（両側：6 例), 分類は直接型：12例, 間接型：22例，再発型：3例であった。以上の因子に 対して 2 群間の症例の分布に統計学的有意差は認めら れず，検討する母集団に差異のないものと考えた。

\section{2) 方法}

手術方法として, Kugel 法は Kugel ${ }^{2)}$, 小山ら 法に従い行った、メッシュプラグ法は Robbinsらクの 方法に準し，さらに onlay patchのずれを防ぐため鼠 径管後壁・恥骨結節などを 8〜10針固定を加えた.

検討方法として, Kugel 法, メッシュプラグ法それ ぞれの手術時間の推移, 平均手術時間, 再発, 合併症, 平均在院日数について比較した．また，38例の Kugel 法を前半の19例と後半の19例で分け, 前回手術よりの 間隔（日数）と手術時間についての散布図を作成しそ の傾向を調へたた。

\section{結 果}

平均手術時間は Kugel 法29.6分 (10 95分), メッシ ュプラグ法47.3分 (23〜85分), 特に初期の症例を除い た最近20症例の平均手術時間を比較したところ, Kugel 法21.9分 (12〜43分)，メッシュプラグ法36.3分 （23〜65分）と Kugel 法の方が短かい傾向にあった (表 1 ).

Kugel 法の手術時間の推移をグラフでみると，15例 目を過ぎたころから20分前後と安定してきたことが分 かる(図 2 ). また, 前半の19例と後半の19例の前回手 術よりの間隔（日数）と手術時間についての散布図を 作成し直線近似したところ, 前半の症例群では手術間 隔が長いほど手術時間が長くなる傾向を認めたが，後 半の症例群ては手術時間は手術間隔に影警されない結 

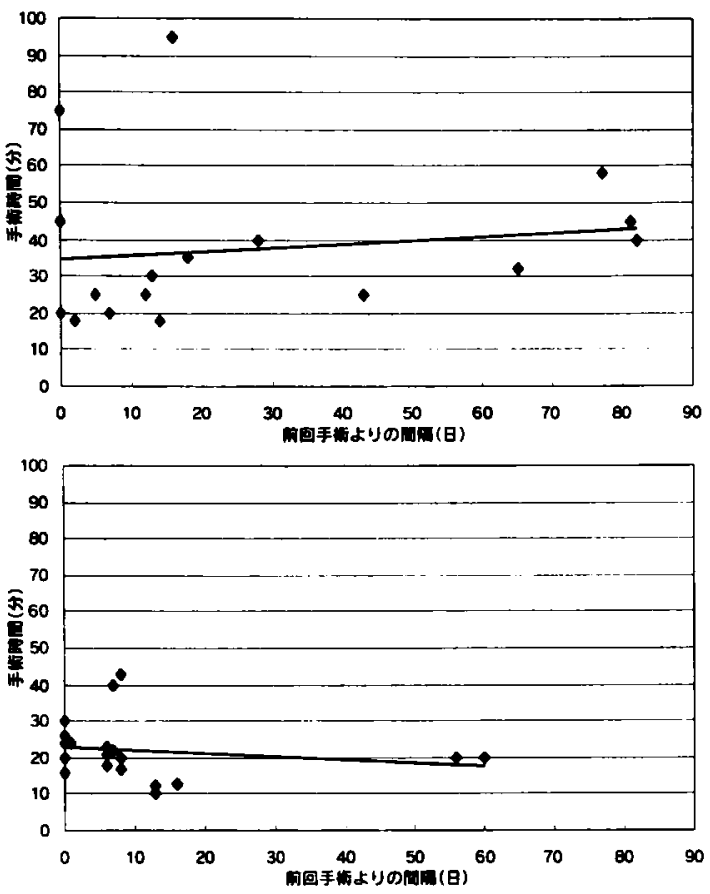

図 3 手術間隔 (日数) と手術時間の関係：A） 2-18症 例目. B) $19-38$ 症例目.

果となった(図3).

Kugel 法,メッシュプラグ法ともに初期の 1 例に再 発を認めた。合併症は Kugel 法に洯液腫 5 例，皮下血 腫 1 例生じたが，穿刺吸引を必要とするほどのもので はなく,いずれも2 週間以内に自然消退した. 両方法 とも術後感染などは生じなかった。平均在院日数は, 広域の医療圈を抱えるという当院の事情もあり，他院 と比較しても長めとは考えられるが，Kugel 法6.7日， メッシュプラグ法6.9日であった（表 1 ).

\section{考 察}

Kugel 法が報告されて以来，その多くの利点から， わが国でもこの方法が徐々に広まりつつある．具体的 には, Kugel 法は onlay patch repair であるメッシュ プラグ法と比較すると，物理的に強固な補強となる underlay patch repairであり有利である.また, Kugel 法は腹膜前腔アプローチであるため, 鼠径管を開放す ることがなく，神経損傷などの合併症もない，そして， 腹膜前腔に広く Kugel パッチを当てるため，すへてての タイプのヘルニア (直接型, 間接型, 大眼ヘルニア) に対応可能であることも有利な点でる.また, Kugel 法の術式は，実際には腹膜前腔を例離して Kugel パッ
チを挿入するだけで,パッチの固定も 1 針のみであり， 圧倒的に手術操作数の少ない単純なものである。一方 で, 鏡視下手術と比較しても腹腔鏡手術機器や全身麻 酔などを必要とせず低コストであり，約 $3 \mathrm{~cm}$ の小切 開創で直視下に短時間に行える点などが挙げられる。 また, Kugel 2)の報告では，808例に本法を施行し，再発 は初期の 5 例 $(0.62 \%)$ のみであり，再発率の低さも その利点の一つである.

メッシュプラグ法などの巤径管を開放する前方アプ ローチで行う術式は，従来からへルニア手術を行って きた人にも受け入れ易かったが, Kugel 法で用いる腹 膜前腔アプローチは，実際には単純な術式であるもの の, 解剖学的に馴染みが薄く理解しにくいなどの理由 から，敬遠されがちである8．われわれも，当初は見慣 れぬ術野に戸惑いを党えたが，症例を重枋るにつれ， 確実な手術を安定した手術時間で行えるようになって きた．患者の体格などにもよるが，手技が安定した時 期ではほほ20分程度で施行できるようになった．今回 の検討でも，Kugel 法はメッシュプラグ法と比較して 手術時間は短い傾向にあり，入院期間や再発などの結 果においてもほほ同等の成績であった。

Kugel 法では 4 例目の症例で再発を認めたが，これ は内側方向への剶離が不十分であったことから Kugel パッチがめくり返り，その部分からへルニアが再発し たものであった，それ以後は腹膜前县の充分な剶離を 行い, Kugel パッチが十分に広い範囲を覆うように心 掛けている.

今回の検討から，手術経験年数などにも若干影響を 受けることが予想されるが, 一人の術者が Kugel 法の 安定した手技を確立するためには，少なくとも15例か ら20例の症例数を，集中的に経験することが望ましい と考えられた。

また, Kugel 法を理解すれば, 促来法やメッシュプ ラグ法の再発に対しても容易に対応することが可能と なる.当科では，そのような再発症例に対しては Kugel 法よりもやや大きな皮痛切開を置き, Kugel パッチ(S または $\mathrm{M}$ サイズ）を用いた腹膜前修復法9で行ってい るが,これは再発の可能性の低い確実な方法である. また，閉鎖孔へルニアの場合にも槑離範囲を広げ Kugel パッチを当てるなどの応用が出来ることも挙げ られる(10)11).

\section{結 語}

Kugel 法は手技の安定に少なくとも15例から20例の 症例経験を要するものの, 習熟すればメッシュプラグ 
法よりも短時間で施行できる傾向にあった．Kugel 法 はメッシュプラグ法と比較して，手術操作も少なく術 式も単純であり，物理的に強固であることなど多くの 利点を持つ, 成人鼠径へルニアの非常に有用な術式と 考えられる。

\section{文 献}

1) 柵瀨信太郎：成人圂径ヘルニアの手術. メッシュ を用いた瓦径ヘルニア手術.外科治㞠 $84: 393-$ 404,2001

2) Kugel $\mathrm{RD}$ : Minimally invasive nonlaparoscopic, preperitoneal, and sutureless, inguinal herniorrhaphy. Am J Surg 178 : 298-302, 1999

3）山田高嗣, 石川博文, 山本克彦他：成人鼠径へル ニアに対するクーゲル法恶入の初期検討. J Nara Med Ass 55:161-168, 2004

4）池田政宣, 小野栄治, 嶋谷邦彦他：Kugel patch を 用いた成人鼠径ヘルニア手術20例の検討. 広島医 $58: 364-367,2005$

5) Branum GD : Minimally invasive open-preper- itoneal herniorrhaphy. Operative Techniques in General Surgery 1:203-210, 1999

6）小山 勇, 上笹 直, 利光靖子他：Kugel 法。外 科治療 $88: 172-179,2003$

7) Robbins AW, Ruktow IM : The mesh-plug hernioplasty. Surg Clin North Am $73: 501-512$, 1993

8）小山 勇，多賀 誠，利光靖子他：Kugel Patch を用いた成人鼠径ヘルニア修復術.消外 $27: 535$ $-542,2004$

9）柵瀨信太郎：再発鼠径へルニアの治療, Preperitoneal approach と meshによる㭪強について. 消外 $15 ： 1483-1494,1992$

10）金廣括也，津村裕昭，市川 徹他：Kugel Patch を用いた腹膜外修復法を行った閉鎖孔ヘルニアの 1 治験例. 広島医 $58: 235-238 ， 2005$

11）星野敏彦, 遠藤正人, 外浦 功他：Kugel Patch を用いた閉銷孔へルニアの 1 例. 日臨外会誌 $66: 2857-2861,2005$

\title{
THE SUPERIORITY OF KUGEL METHOD COMPARED TO MESH PLUG METHOD FOR INGUINAL HERNIA IN ADULTS
}

\author{
Shintaro KURODA, Kei KOIDE*, Nobuaki FUJIKUNI**, Narihiro AKIMOTO*, \\ Koichi OISHI*, Takayuki KADOYA*, Saburo FUKUDA*, Hideto SAKIMOTO*, \\ Takaaki ETO* and Makoto TAKAHASHI* \\ Department of Surgery, Akane Foundation Tsuchiya General Hospital \\ -Department of Surgery, Chugoku Rosai General Hospital \\ - Department of Surgery, National Hospital Organization Higashihiroshima Medical Center
}

Among many operative procedures for inguinal hernia in adults, Kugel method which has a variety of benefits has increasingly employed in recent years. Compared with other tension free procedures, Kugel method is a simple procedure requiring less operative manipulations. However, it is a difficult point of Kugel method that the acquaintance of skill demands experiences in some degree, because we are anatomically unfamiliar to the preperitoneal cavity at where a patch is placed. In this study we calculated the learning curve of operating time in 38 cases in which one surgeon had performed Kugel method for 16 months after the introduction of it, in order to draw the number of cases to acquire the skill. Moreover a comparison was made between these 38 cases and another 37 cases in which mesh plug method was performed before the introduction of Kugel method. Average operating time was $29.6 \mathrm{~min}$ in Kugel method versus $47.3 \mathrm{~min}$ in mesh plug method. It is inferred that reliable operating skill is able to be attained by experiences with $15-20$ cases for one surgeon. Although Kugel method demands experiences in some degree, once surgeons are versed in the technique and the method would become an advantageous method which would promise reliable performance in a very short time. 